\title{
Correction to: A pooled analysis of the LAMP assay for the detection of Neisseria meningitidis
}

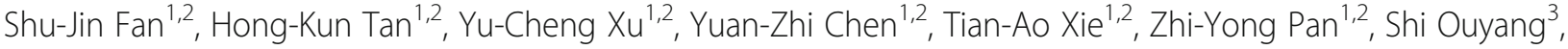 \\ Qin $\mathrm{Li}^{4}$, Xiao-yan $\mathrm{Li}^{5}$, Zhen-Xing $\mathrm{Li}^{6}$ and Xu-Guang Guo ${ }^{1,2,7,8^{*}}$
}

\section{Correction to: BMC Infect Dis (2020) 20:525 https://doi.org/10.1186/s12879-020-05250-w}

Following publication of the original article [1], the authors identified an error in the author name of $\mathrm{dr}$. Shi Ouyang.

The incorrect author name is: Shi-Ou Yang

The correct author name is: Shi Ouyang

The author group has been updated above and the original article [1] has been corrected.
Published online: 31 July 2020

\section{Reference}

1. Fan S-J, et al. A pooled analysis of the LAMP assay for the detection of Neisseria meningitidis. BMC Infect Dis. 2020;20:525 https://doi.org/10.1186/ s12879-020-05250-w.

\begin{abstract}
Author details
'Department of Clinical Laboratory Medicine, the Third Affiliated Hospital of Guangzhou Medical University, Guangzhou 510150, China. ${ }^{2}$ Department of Clinical Medicine, the Third Clinical School of Guangzhou Medical University, Guangzhou 511436, China. ${ }^{3}$ Department of infectious disease, The Fifth Affiliated Hospital of Guangzhou Medical University, Guangzhou, China. ${ }^{4}$ Pulmonary, Critical Care and Sleep Medicine, Yale School of Medicine, New Haven, USA. ${ }^{5}$ Department of Laboratory Medicine, The Affiliated Shunde Hospital of Guangzhou Medical University, Foshan, China. ${ }^{6}$ Department of respiratory, The third Affiliated Hospital of Guangzhou Medical University, Guangzhou, China. ${ }^{7}$ Key Laboratory for Major Obstetric Diseases of Guangdong Province, Guangzhou 510150, China. ${ }^{8}$ Key Laboratory of Reproduction and Genetics of Guangdong Higher Education Institutes, Guangzhou 510150, China.
\end{abstract}

The original article can be found online at https://doi.org/10.1186/s12879020-05250-w.

* Correspondence: gysygxg@gmail.com

'Department of Clinical Laboratory Medicine, the Third Affiliated Hospital of Guangzhou Medical University, Guangzhou 510150, China

${ }^{2}$ Department of Clinical Medicine, the Third Clinical School of Guangzhou Medical University, Guangzhou 511436, China

Full list of author information is available at the end of the article

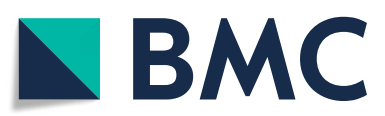

() The Author(s). 2020 Open Access This article is licensed under a Creative Commons Attribution 4.0 International License, which permits use, sharing, adaptation, distribution and reproduction in any medium or format, as long as you give appropriate credit to the original author(s) and the source, provide a link to the Creative Commons licence, and indicate if changes were made. The images or other third party material in this article are included in the article's Creative Commons licence, unless indicated otherwise in a credit line to the material. If material is not included in the article's Creative Commons licence and your intended use is not permitted by statutory regulation or exceeds the permitted use, you will need to obtain permission directly from the copyright holder. To view a copy of this licence, visit http://creativecommons.org/licenses/by/4.0/ The Creative Commons Public Domain Dedication waiver (http://creativecommons.org/publicdomain/zero/1.0/) applies to the data made available in this article, unless otherwise stated in a credit line to the data. 